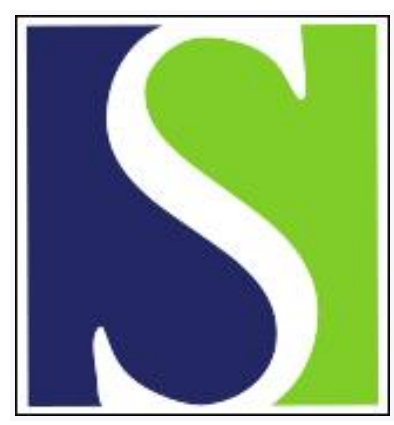

Scand J Work Environ Health 1994;20(2):128-131

https://doi.org/10.5271/sjweh.1421

Issue date: 01 Apr 1994

Associations between safety and contingency measures and occupational accidents on offshore petroleum platforms.

by Rundmo T

Affiliation: University of Trondheim, Department of Psychology, Dragvoll, Norway.

This article in PubMed: www.ncbi.nlm.nih.gov/pubmed/8079134

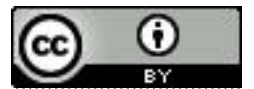




\title{
Associations between safety and contingency measures and occupational accidents on offshore petroleum platforms
}

\author{
by Torbjørn Rundmo, $\mathrm{PhD}^{1}$
}

RUNDMO T. Associations between safety and contingency measures and occupational accidents on offshore petroleum platforms. Scand J Work Environ Health 1994;20:128-31.

\begin{abstract}
OBJEctives - The primary purpose of this study was to determine the association between organizational factors and accidents among employees on the Norwegian continental shelf.

MerHods - A self-administered survey among offshore petroleum personnel was conducted in the spring of 1990. The survey drew respondents from five companies and eight platforms. The response rate was $92 \%(\mathrm{~N}=915)$.

REsulTs - Substantial correlations were found between management and employee commitment and involvement in safety work, social support, attitudes towards safety measures, the personnel's satisfaction-dissatisfaction with the safety and contingency measures and accident frequency.

Conclusions - Employee satisfaction-dissatisfaction was associated with injury rates, and also with other organizational factors. The credibility of the theory that employee perception of safety and contingency measures mirrors the status of accident prevention work was enhanced.
\end{abstract}

KeY TERMS - accident prevention, accidents, management commitment, management involvement, occupational health, social support.

Employee perception of safety and contingency measures has been found to be the most important factor for perceived job stress and subjective risk assessment among personnel on offshore oil platforms in the North Sea $(1,2)$. Job stress and perceived risk was also significantly correlated with the number of accidents and near-accidents on such installations. Therefore it was relevant to uncover organizational and social factors exerting influence on the personnel's satisfaction-dissatisfaction with safety and contingency measures (3). This information is especially important if these factors also affect accident risk.

Self-administered surveys disclose the respondents' subjective evaluations. One can then ask how consistently do these evaluations portray the real status of accident prevention work. Dunham (4) showed that employee assessments of job characteristics were consistent with "objective" evaluations of the same factors. Likewise, employee and supervisor assessments of job characteristics are significantly correlated. The perception of job characteristics reflects the type of job and the technology and position of the respondent (4-8). If the respondents perceive safety and contingency measures in a "realistic" way, greater dissatisfaction on oil platforms should be ex-

1 University of Trondheim, Department of Psychology, Dragvoll, Norway.

Reprint requests to: $\mathrm{Dr} \mathrm{T}$ Rundmo, University of Trondheim, Department of Psychology, N-7055 Dragvoll, Norway. pected where the injury frequency rate is high ("high injury platforms") than on platforms where the rate is low ("low injury platforms"). In contrast, the respondents' own experience of accidents can also influence their perception of these factors.

The empirical consequences will be the same both when employees perceive safety and contingency measures in a "realistic" way and when experience with accidents shapes their perceptions. For practical reasons it can be difficult to conduct controlled experiments to test these attitudes. However, by comparing satisfaction-dissatisfaction on low- versus high-injury platforms for personnel having the same injury experience, one may be able to enhance the credibility of the theory that employee perception of safety and contingency measures "realistically" mirrors the status of the accident prevention work at the sites in question. Separate analyses must therefore be conducted of employees who themselves have been injured and of those who have never suffered an injury.

If differences are found in satisfaction-dissatisfaction on low-injury and high-injury platforms in groups of personnel having the same injury experience, the credibility of the theory that the personnel's subjective assessment reflects the true status of accident prevention is heightened. Therefore the satisfaction-dissatisfaction of workers without records of injury (ie, those who themselves have not experienced an accident when conducting their work) on platforms having low versus high accident experiences must be compared with the satisfaction-dissat- 
isfaction of workers with records of injury (ie, who themselves have experienced an accident) on platforms having low versus high accident exposure. It is important to analyze these relations in order to be able to outline efficient preventive measures and promote safety.

The specific objective of this paper was thus to examine how consistently employee evaluations of safety and contingency measures portray the real status of accident prevention measures on board by analyzing the relations between the employees' evaluations of safety and contingency measures in relation to their accident experience.

\section{Subjects and methods}

Sample

A sample intended to be representative of the offshore petroleum industry on the Norwegian Continental Shelf was selected. It came from eight platforms and five companies. The response rate was 92\% $(\mathrm{N}=915)$. (See also reference 3.)

\section{Measures}

The respondents were asked to assess their satisfaction with the safety and contingency factors on the oil platform on which they worked, management and employee commitment, involvement in safety work, social support from management, supervisors and colleagues, and their own attitudes towards safety measures. Fifty test items were used to measure these aspects. (See reference 3 for a description of these indices.) In addition, the respondents' own experience with occupational accidents and "near-accidents" was measured.

The respondents were asked to report whether they had experienced accidents in their time offshore or not and whether they had been exposed "many times," "once," or "never" to a situation or incident which could easily have led to injury.

The ratio between self-reported accidents and "near-accidents" was 1:3. Accident figures published annually by the Norwegian Petroleum Directorate (9) and the respondent's self-reported accident frequency were compared. Accident figures, as well as self-reported frequencies, were given range values separately for maintenance and construction personnel, operator personnel, drillers, and technical-mechanical personnel, and the range values were identical for statistical figures from the Norwegian Petroleum Directorate and self-reported range values. The self-reported data were found to be valid (10).

\section{Analysis}

Because of the great number of single items used in the measurement, it was first considered necessary to replace single test items by indices which depicted the underlying structure of the evaluations (belief dimensions). Principal component analysis was used to detect the underlying factors. (See reference 3.)

For each individual the scores on test items belonging to a certain index were then added without differential weighting, and a score for each dimension was determined. For testing the differences in significance due to the respondents' injury experience (ie, whether or not they themselves had been injured), the chi-square test and the t-test were used.

\section{Results}

The employees' degree of satisfaction-dissatisfaction with safety and contingency measures was dependent on whether they themselves had been injured while carrying out his work duties. Those who had never been injured were compared with those who had been injured. The differences were significant for protective measures $(\mathrm{t}=3.61, \mathrm{~N}=857, \mathrm{P}=$ $0.000)$, instructions $(\mathrm{t}=3.70, \mathrm{~N}=859, \mathrm{P}=0.000)$, and training $(\mathrm{t}=3.30, \mathrm{~N}=863, \mathrm{t}=0.001)$. Those who themselves had been injured were more dissatisfied than those who had never been injured. The results can be explained as follows: (i) a respondent's own injury experience was significantly correlated with dissatisfaction and (ii) the fact that safety and contingency measures prevent accidents brings about satisfaction with these conditions. The personnel's perception of the situation is "realistic" and mirrors the true status of the accident prevention work on the platform.

The number of accidents varied due to platform $\left(\chi^{2}=14.25\right.$, degrees of freedom $(\mathrm{df})=7 / 884, \mathrm{P}=$ $0.047)$. Satisfaction-dissatisfaction among the personnel on platforms where the number of accidents was greater than expected ("high-injury platforms") was compared with that among personnel on platforms where the number was lower than expected ("lowinjury platforms"). The number of platforms was four in both groups. As seen in table 1 the employees were more dissatisfied with the safety and contingency measures on the high-injury platforms than they were on the low-injury platforms.

Separate analyses were conducted of employees who themselves had been injured and those who had never suffered an injury during their time offshore. Satisfaction among personnel with the same injury experience on low-injury and high-injury platforms was compared. Among employees who had never experienced an accident themselves, the differences in satisfaction-dissatisfaction were significant due to platform.

However, in the group of persons who had been injured, there were no statistically significant differences due to platform category (table 2). There can be various reasons for this finding. The personnel's perceptions could have been closer to the "objective" risk among the uninjured employees than among the injured ones. Hence, the respondents could have been 
Table 1. Number of persons not satisfied a with the safety and contingency measures on low-injury and high-injury platforms ( $F_{\text {exp }}=$ expected values and $F_{\text {obs }}=$ observed values)

\begin{tabular}{|c|c|c|c|c|c|c|}
\hline & \multicolumn{2}{|c|}{ Low-injury platforms } & \multicolumn{2}{|c|}{ High-injury platforms } & \multirow{2}{*}{$\chi^{2}$} & \multirow{2}{*}{ P-value } \\
\hline & $F_{o b s}$ & $F_{\text {exp }}$ & $F_{o b s}$ & $F_{\text {exp }}$ & & \\
\hline \multicolumn{7}{|l|}{ Employment condition } \\
\hline \multicolumn{7}{|l|}{ Injured personnel } \\
\hline $\begin{array}{l}\text { Operator personnel } \\
\text { Contractor personnel }\end{array}$ & $\begin{array}{l}17 \\
32\end{array}$ & $\begin{array}{l}22 \\
27\end{array}$ & $\begin{array}{l}83 \\
91\end{array}$ & $\begin{array}{l}78 \\
96\end{array}$ & 2.12 & NS \\
\hline \multicolumn{7}{|l|}{ Uninjured personnel } \\
\hline $\begin{array}{l}\text { Operator personnel } \\
\text { Contractor personnel }\end{array}$ & $\begin{array}{r}127 \\
69\end{array}$ & $\begin{array}{r}112 \\
84\end{array}$ & $\begin{array}{l}222 \\
192\end{array}$ & $\begin{array}{l}192 \\
177\end{array}$ & 6.09 & 0.014 \\
\hline \multicolumn{7}{|l|}{ Personnel group } \\
\hline \multicolumn{7}{|l|}{ Injured personnel } \\
\hline \multirow{2}{*}{$\begin{array}{l}\text { Group I (administration, } \\
\text { production, catering) } \\
\text { Group II (drilling, maintenance } \\
\text { technical-mechanical) }\end{array}$} & 12 & 11 & 42 & 43 & & \\
\hline & 30 & 31 & 118 & 117 & 0.01 & NS \\
\hline \multicolumn{7}{|l|}{ Uninjured personnel } \\
\hline \multirow{2}{*}{$\begin{array}{l}\text { Group I (administration, } \\
\text { production, catering) } \\
\text { Group II (drilling, maintenance, } \\
\text { technical-mechanical) }\end{array}$} & 92 & 82 & 169 & 179 & & \\
\hline & 77 & 87. & 199 & 189 & 3.03 & 0.082 \\
\hline
\end{tabular}

a "Not satisfied" = "neutral," "dissatisfied," and "strongly dissatisfied".

Table 2. High- versus low-injury platform differences in the respondents' ratings of satisfaction - dissatisfaction with the safety and contingency measures. (NS = not significant)

\begin{tabular}{lccccc}
\hline & \multicolumn{2}{c}{ Uninjured personnel } & & \multicolumn{2}{c}{ Injured personnel } \\
\cline { 2 - 3 } \cline { 5 - 6 } & t.Value & P-value & & t-Value & P-value \\
\cline { 2 - 3 } Protective measures & 5.12 & 0.000 & & 1.84 & NS \\
Instruction & 4.28 & 0.000 & & 1.59 & NS \\
Training & 2.52 & 0.012 & & 1.77 & NS \\
\hline
\end{tabular}

satisfied primarily because the platform had given high priority to safety and contingency measures and not because of their own injury experiences. Since the uninjured employees know the dangers, they are able to tell which measures are necessary for successful accident prevention. They are also able to avoid dangerous situations. Consequently they are not so frequently subject to injury as those whose perceptions are less "objective."

The personnel's assessments mirror the true situation in both the group with injuries and that without. An oil platform is a complex organization employing several personnel groups engaged in various duties. Accident frequency and objective risk depend on the personnel group and employment conditions $(11,12)$. Drilling personnel, maintenance and construction personnel, and technical-mechanical personnel experienced the greatest risk ("high-risk personnel"), while administration, production, and catering personnel experienced the smallest objective risk ("low-risk personnel"). Contractor personnel experienced greater risk than operator personnel.

If the percentage of the persons in the group of high-risk personnel who are operators and contrac- tors is the same on both high- and low-injury platforms, the assumption that the assessments are closer to "objective" risk estimates also in these personnel groups gains greater credibility. The chi-square test confirmed this possibility $\left(\chi^{2}=2.12\right.$, df 1 , not significant). Nor was the group of injured personnel expected to have any differences in the number of persons belonging to high-risk and low-risk groups both on low-injury and high-injury platforms. This expectation was also confirmed $\left(\chi^{2}=4.41\right.$, df 6 , not significant). The results show that (i) the satisfactiondissatisfaction with safety and contingency measures among the personnel were "realistic" (ie, they mirrored the true status of the accident prevention work on the platform and (ii) the conditions affected the number of occupational injuries.

\section{Discussion}

This study compared satisfaction-dissatisfaction on low- versus high-injury oil platforms. The credibility was heightened of the theory that employee perception of safety and contingency measures "realistically" mirrors the status of accident prevention work on oil platforms.

When matched pairs of the management of manufacturing firms have been compared (13-16), commitment and involvement has been the factor most frequently found to characterize firms achieving low accident figures in comparison with firms with high accident rates. In these studies matched pairs of companies were selected so that two members of each pair were comparable. Both firms in each of the pairs were located in the same area, were in the same in- 
dustry, and were approximately of the same size. However, the firms in each pair had marked differences in accident frequency. Greater management commitment and involvement in safety matters was found to be related to lower accident rates. Other important factors found to separate low-injury and high-injury firms were work-force stability, stringent housekeeping, control and inspection routines, formalized accident reporting systems, and frequent positive contact between employees and supervisors regarding safety matters. (See also reference 17 for a review of the literature.) In these studies low versus high accident rates were considered an effect of the safety program factors. The studies did not fully meet the demands for inferring causal relations. However, to study these factors "experimentally" gives rise in most cases to both practical and ethical problems $(18,19)$ that make such a design difficult or impossible to carry out.

In the present study it was found that employee perception of greater management commitment and social support were associated with lower injury rates. In addition, the validity of employee self-report data was established through a comparison of employees' reports of safety measures to injury rates. Improving the factors contributing to the variance in satisfaction-dissatisfaction with the safety and contingency measures will therefore probably also lead to real improvements in these measures. There is reason to believe that any improvement of the real status will affect the accident frequency rate and reduce the number of accidents taking place.

\section{Acknowledgments}

Financial support for the study was provided by the Norwegian Petroleum Directorate.

Ms I Årstad, Senior Engineer, and Mr P Saltrø, Manager of the Safety Department at the Norwegian Petroleum Directorate, provided important assistance during the study. The author also wishes to thank the participating petroleum companies for their cooperation and the personnel on the platforms, who took the time to answer the questionnaire.

\section{References}

1. Rundmo T. Risk perception and safety on offshore petroleum platforms - part I: perception of risk. Saf Sci 1992;15:39-52.

2. Rundmo T. Risk perception and safety on offshore petroleum platforms - part II: perceived risk, job stress and accidents. Saf Sci 1992;15:53-68.

3. Rundmo T. Associations between organizational factors and safety and contingency measures on offshore petroleum platforms. Scand J Work Environ Health
1994;20:122-7.

4. Dunham RB. Relationships of perceived job design characteristics to job quality requirements and job value. J Appl Psychol 1977;62:760-3.

5. Aldag RJ, Barr, SH, Brief AP. Measurement of perceived task characteristics. Psychol Bull 1981;90: $415-31$.

6. Pierce JL, Dunham RB. The measurement of perceived job characteristics: the job diagnostic survey versus the job characteristic inventory. Acad Manage J 1978; 1:123-8.

7. Marek J, Iversen E, Hellesøy OH. Hvor viktig er organisasjon, sosiale forhold og sikkerhetstiltak for risikokontroll og generell sikkerhet? Operatøransatte på statfjordfeltet vurderer sine jobber [How important are organization, social conditions and safety measures for control of risk sources and safety? Operator personnel on the Statfjord field evaluate their jobs]. Bergen: Forskningssenter for arbeidsmiljø, helse og sikkerhet, 1986.

8. Marek J, Iversen E, Hellesøy OH. Experience of risk and safety. In: Hellesøy OH, ed. Work environment Statfjord field: Work environment, health and safety on a North Sea oil platform. Oslo: Universitetsforlaget, 1985:142-74.

9. Norwegian Petroleum Directorate (NPD). Annual reports. Stavanger: The Norwegian Petroleum Directorate, $1985-1988$.

10. Rundmo T. Opplevd risiko og sikkerhet. Resultatrapport [Risk perception and safety: main report]. Stavanger/Trondheim: Foundation of Scientific and Industrial Research, 1990. (Research report; STF75 A90034.)

11. Rundmo T. Risk perception and safety: summary report. Stavanger: The Norwegian Petroleum Directorate, 1991.

12. Rundmo T. Organization, safety measures and perception of risk on two offshore installations. Oslo: Institute of Transport Economics, 1991. (TØI-report; no 0089.)

13. Cohen A. Factors in successful occupational safety programs. J Saf Res 1975;9:168-78.

14. Simonds RH, Shafai-Sahrai Y. Factors apparently affecting injury frequency in eleven matched pairs of companies. J Saf Res 1977;9:120-7.

15. Smith MJ, Cohen HH, Cohen A, Cleveland RJ. Characteristics of successful safety programs. J Saf Res 1987; 10:5-15.

16. Smith MJ, Cohen A, Cleveland RJ, Cohen HH. Safety program practices in recordholding plants. Morgantown, WV: National Institute of Occupational Safety and Health, United States Department of Health, Education and Welfare, 1979.

17. Rundmo T, Saari J. Kontrollitekniikat [Control techniques]. In: Hovden J, ed. Inhimillinen erehdys - kirjallisuuskatsaus turvallisen käyttytymisen ohjauskeinoista [Safe behaviour - accident prevention measures]. Tampere (Finland): Tampere University of Technology, Department of Mechanical Engineering, 1988:39-88. (Occupational safety engineering report; no 50.$)$

18. Goldstein H. Multilevel models in educational and social research. London: Charles Griffin \& Company Ltd, 1987.

19. Hellevik, O. Introduction to causal analysis: exploring survey data by crosstabulation. Oslo: Norwegian University Press, 1988.

Received for publication: 2 July 1993 